\begin{tabular}{|c|c|c|}
\hline 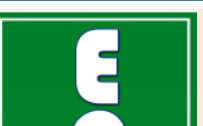 & $\begin{array}{l}\text { International Journal of Current Research in } \\
\text { Biosciences and Plant Biology }\end{array}$ & $=$ \\
\hline & Volume 8 • Number o8 (August-2021) • ISSN: 2349-8080 (Online) & \\
\hline $\begin{array}{l}\text { EXCELLENT } \\
\text { PUBLISHERS }\end{array}$ & Journal homepage: $\underline{w w w . i j c r b p . c o m}$ & \\
\hline
\end{tabular}

Review Article

doi: https://doi.org/10.20546/ijcrbp.2021.808.003

\title{
Triphala: An Indian Ayurvedic herbal formulation for coronavirus (SARS- CoV-2) disease (Covid-19)
}

\author{
Ravindra B. Malabadi ${ }^{1,2 *}$, Kiran P. Kolkar ${ }^{3}$, Neelambika T. Meti ${ }^{4}$, Raju K. Chalannavar ${ }^{1}$ \\ ${ }^{1}$ Department of Applied Botany, Mangalore University, Mangalagangotri-574 199, Mangalore, Karnataka State, India \\ ${ }^{2}$ Miller Blvd, NW, Edmonton, Alberta, Canada \\ ${ }^{3}$ Department of Botany, Karnatak Science College, Dharwad-580003, Karnataka state, India \\ ${ }^{4}$ Plant Biotechnology Laboratory, Rajiv Gandhi Institute of IT and Biotechnology, Bharati Vidyapeeth University, \\ Pune-Satara Road, Katraj, Pune - 411046, Maharashtra State, India \\ *Corresponding author; e-mail: rbmalabadi_b3g@ yahoo.com
}

\begin{abstract}
Article Info
Keywords:

Covid-19

Herbal medicine

Pumpkin seeds

Triphala

Viral infections

Abstract

This review paper updated the significance and pharmaceutical effects of Triphala as an alternative traditional herbal Indian folk medicine used as a immunity booster during the recent outbreak of coronavirus-2 (SARS-CoV-2) mutants, Delta (B.1.617.2) and Delta Plus (AY.1). The current outbreak of coronavirus-2 mutants, Delta (B.1.617.2) and Delta Plus (AY.1) is wreaking havoc in India. The new epicentre of the highest number of corona viral mutant infection cases and death rate has been recorded in Indonesia. The hallmark of the coronavirus disease is the cytokine storm, a massive cytokine and chemokine release due to an uncontrolled dysregulation of the host immune defence that causes loss of function of multiple organs and leading to death. One of the evidence to support Triphala alone inhibited the RNA viruses including human coronavirus. Triphala herbal formulation can reduce the production of progeny of human coronavirus, HCoV-NL63 particles and have an antiviral effect under in vitro conditions. In India, Triphala herbal formulation with an additional supplementation of pumpkin seeds, coconut water, sugar cane juice, Aloe vera juice, neem (Azardirachta indica) leaf juice, and melatonin rich diet has played an important role in controlling coronavirus disease than Triphala alone. However, clinical trials of Triphala with new additional supplementations is lacking for the scientific validation. On the basis literature survey, there is a ray of hope for the Triphala with additional supplementation as a new therapeutic drug for combating Covid19 viral infections.
\end{abstract}

- Received: 09 June 2021 • Revised: 27 July 2021 • Accepted: 02 August 2021・Published Online: 6 August 2021

\section{Introduction}

The outbreak of second wave of coronavirus (SARSCoV-2) mutants, Delta (B.1.617.2) and Delta Plus (AY.1) with mucormycosis has devastated India by more number of hospitalizations and increased death rates (Mlcochova et al., 2021; Malabadi et al., 2021a, 2021b, 2021c, 2021d, 2021e, 2021f, 2021g, 2021h; Yang, 2021). Therefore, the outbreak of Delta (B.1.617.2) and Delta Plus (AY.1) mutants pandemic has created a global health crisis posing an unprecedented public health emergency. The Delta plus 
variant (AY.1) is related to the Delta strains, an existing variant of concern thought to have driven the deadly second wave of infections on 11th April month of 2021 in India (Malabadi et al., 2021g). This second wave of mutant, Delta (B.1.617.2) and Delta Plus (AY.1) outbreak in India has created lot of problems, viral infections were out of control, shortage of oxygen supply and bed facilities in the hospitals with highest number of deaths, and becomes challenge to the Indian health care system (Mlcochova et al., 2021; Malabadi et al., 2021g, 2021f). At this critical situation in India, health care workers have exhausted, medical facilities are not enough due to the shortage of supply, hospitals are over-crowded, and many people are infected due to cross contamination of the virus. Social media is full of desperate people (doctors, nurses, health care workers and the public) seeking medical oxygen, hospital beds, and other necessities (Malabadi et al., 2021f). Therefore, Government of India has put strict lock down measures to curb the growth curve of the virus. This has ruined the economy of India on one side and on the other side Covid-19 control measures were effective. This Delta plus variant (AY.1) has also been found in nine other countries like in USA, UK, Portugal, Switzerland, Japan, Spain, Poland, Nepal, Russia and China as compared to the original highly contagious Delta strain, which has now spread to 80 countries throughout globe (Mlcochova et al., 2021; Malabadi et al., 2021g, 2021f). According to WHO report, everybody is vulnerable and people should continue to using masks and to avoid crowds, even if they're fully vaccinated.

Indonesia has become the new epicentre of the pandemic, surpassing India and Brazil to become the country with the world's highest count of new viral infections in non-vaccinated people. Every infected person, anywhere in the world, offers the coronavirus another opportunity to morph into a new variant. The more infections there are globally, the more likely new variants will arise. Therefore, unvaccinated people are not protected and will set the country on fire over and over again. Vaccinated people will be protected from severe illness and death, but there may be other consequences. There are also concern about fully vaccinated people might become infected. Breakthrough infections were expected to be vanishingly rare with the original virus. However, recent data suggested that they may be less so with the delta variant. It is roughly twice as contagious as the original coronavirus, and some early evidence hints that people infected with the corona virus variant carry the virus in much higher amounts. "The larger the force of infection that comes from the pandemic in unvaccinated populations.

The Delta variant of coronavirus (SARS-CoV-2) is becoming the globally dominant version of the disease (Mlcochova et al., 2021; Malabadi et al., 2021f, 2021g). India's first wave of SARS-CoV-2 infections has started in March 2020 was relatively mild and was controlled by a nationwide lockdown (Mlcochova et al., 2021). Delta variant's (B.1.617.2) of concern increased transmissibility has enhanced spike proteins attachment to the lung epithelial cells, which provided a much higher capacity to infect many more people than the original Wuhan strain (Wu et al., 2020a, 2020b; Zhou et al., 2020a, 2020b; Mlcochova et al., 2021; Malabadi et al., 2021g). The SARS-CoV-2 Delta mutant, B.1.617.2 variant was first identified in the state of Maharashtra, India and has spread throughout India, displacing the B.1.1.7 (Alpha) variant and other pre-existing lineages (Mlcochova et al., 2021; Malabadi et al., 2021g, 2021f). According to the study reported by Mlcochova et al., (2021), the Delta variant (B.1.617.2) showed 8 fold approximately reduced sensitivity to vaccineelicited antibodies compared to wild type Wuhan-1 bearing D614G (Mlcochova et al., 2021). These combined epidemiological and in vitro data indicated that the dominance of the Delta variant (B.1.617.2) in India has been most likely driven by a combination of evasion of neutralising antibodies in previously infected individuals and increased virus infectivity (Mlcochova et al., 2021). The breakthrough transmission clusters in hospitals associated with the Delta variant (B.1.617.2) are concerning and indicated that infection control measures need to continue in the post-vaccination era (Mlcochova et al., 2021).

The outbreak of Delta Plus (AY.1) variant which is more infectious than previous mutated strains of covid19 (Mlcochova et al., 2021; Malabadi et al., 2021a; Yang, 2021; Wu et al., 2020a, 2020b; Zhou et al., 2020a, 2020b). The delta Plus (AY.1) strain is characterised by $\mathrm{K} 417 \mathrm{~N}$ mutation in the spike protein of the SARS-CoV2 virus that causes the Covid-19 disease (Mlcochova et al., 2021; Wu et al., 2020a, 2020b; Zhou et al., 2020a, 2020b). The K417N mutation has been associated with "immune escape" phenomenon, which means that the virus is less susceptible to available vaccines or less responsive to any drug therapy (Mlcochova et al., 2021). Delta Plus (AY.1) variant of corona virus (SARS-CoV-2) is 
spreading more easily, binds more easily with ACE2 receptors of lung or respiratory epithelial cells and is potentially resistant to monoclonal antibody therapy, a potent intravenous infusion of antibodies to neutralise the virus (Mlcochova et al., 2021).

India is one the leading country in the world possessing very good Eco-climatic conditions housing wide range of medicinal plants (Malabadi et al., 2007). India is known for the rich biodiversity of several medicinal plants (Malabadi and Nataraja, 2002a, 2002b ; Malabadi et al., 2021a, 2021e, 2021f; Kulkarni et al., 2020; Swamy et al., 2016; Malabadi, 2008; Laddimath and Rao, 2016; Malabadi and Vijayakumar, 2005, 2007 2008; Malabadi et al., 2009, 2010a, 2010b, 2011a, 2011b; Malabadi et al., 2012a, 2012b, 2012c, 2012d; Kambhar et al., 2020; Kawalekar, 2011, 2012; Malabadi et al., 2016a, 2016c, 2016d; Malabadi et al., 2017a, 2017b; Malabadi et al.. 2018). Traditional herbal plants have been used as a source of medicine from ancient times (Malabadi et al., 2007, 2021a; Kawalekar, 2011, 2012; Kambhar et al., 2020; Laddimath and Rao, 2016). Crude plant extracts or isolated secondary metabolites have been observed in phytotherapeutic treatment of various ailments (Malabadi et al., 2007; Malabadi et al., 2021a; Laddimath and Rao, 2016; Kawalekar, 2011, 2012; Sharma, 2009; Kambhar et al., 2020). There are two types of traditional herbal medicinal plant systems, one is codified that is organized Indian system of medicines under the umbrella of Ayurveda, Siddha and Unani (Upadhya et al., 2014). The second one is noncodified that is nothing but local or folk medicine practiced by traditional healers (Malabadi et al., 2007; Upadhya et al., 2014; Laddimath and Rao, 2016; Kambhar et al., 2020; Kawalekar, 2011, 2012).

There are some traditional herbal medicine remedies from Ayush systems which provide relief and alleviate some of the symptoms of Covid-19 (Ministry of Ayush, Government of India, 2020). The medicines selected in the protocol have immuno-modulatory effect i.e. they tend to strengthen the immunity of a person in a natural way. Ayush systems follow a holistic approach towards disease management and maintaining health of a healthy person. It provides detailed advocacy and interventions for disease prevention (Ministry of Ayush, Government of India, 2020). There are various interventions in Ayush systems which are presently being used in prophylactic approaches as well as in the management of Covid-19, and are providing good results (Ministry of Ayush, Government of India, 2020). The fusion of knowledge of medicinal plants with modern scientific and bio-medical applications can gives us the cost effective and potential new drugs (Sharma, 2009). As such, traditional medicine is of contemporary relevance in India to achieve self reliance in primary health care needs. The survival of age old traditional Folk systems of medicine in India is based on strong belief in the efficacy and success story of herbal medicines (Sharma, 2009). Medicinal plants play an important role in drug development, as these are the source of majority of ingredients in Ayurvedic as well as Modern medicine. Medico-Ethno botanical survey programme has played a pivotal role in the medicinal plant research programmes by the Ministry of Ayush, Government of India, New Delhi, India. These botanical survey programmes are conducted by the Central Council for Research in Ayurvedic Sciences, Ministry of AYUSH, Government of India, New Delhi, India. It is an apex organization for undertaking, coordinating, formulating, developing and promoting research in Ayurvedic sciences on scientific lines.

This review paper highlights about one of the traditional herbal medicine, Triphala used as an alternative approach for controlling coronavirus (SARS-CoV-2) mutants Delta (B.1.617.2) and Delta plus (AY.1). Triphala has been used as a immunity booster with proven biological properties as per the literature survey might play an important role for combating viral outbreaks. However, more clinical trials should be needed for this valuable medicine for the scientific validation. Pharmaceutical properties of Triphala have been discussed.

\section{Triphala: An Indian Ayurvedic formulation}

Triphala (Sanskrit; Tri $=$ three and Phala $=$ fruits) is defined as a well known tri-herbal Indian Ayurvedic formulation consisting of dried fruits of the three plant species, Emblica officinalis (Amalaki or the Indian Gooseberry) (Family-Euphorbiaceae), Terminalia bellirica (Bibhitaki or Karitaki) (FamilyCombretaceae), and Terminalia chebula (Haritaki) (Family-Combretaceae) that are native to the Indian subcontinent (Ozah, 2020; Saxena et al., 2017; Dhanalakshmi et al., 2007; Mukherjee et al., 2006; Baliga et al., 2012, 2013; Baliga, 2010; Peterson et al., 2017; Malabadi et al., 2021a; Rasool and Sabina, 2007; Kumari et al., 2009; Ozah, 2020). In India, this triherbal combination of dried fruits, Triphala is very famous and used as a traditional home remedy for 
combating common cold, throat infections, antimicrobial, antiviral, antibacterial and antifungal infections (Malabadi et al., 2021a; Shanbag, 2015; Pradeep et al., 2016; Peterson et al., 2017; Mamgain et al., 2016; Bhattacharjee et al., 2015). In Karnataka state of India, plants are commonly called as Aalalekai or a Aalale mara in Kannada language for Terminalia bellirica and Terminalia chebula (Malabadi et al., 2021a). Both Terminalia bellirica and Terminalia chebula trees were found abundant in Western Ghats forests of Karnataka, Maharashtra, Goa, Kerala, Tamil Nadu, and Andhra Pradesh. In India, the Terminalia bellirica and Terminalia chebula trees were widely spread and commonly grown in gardens, and roadside as a shade trees. Medicinal plants still play a significant role in primary health care in many developing countries, since natural products constitute a key source of drugs in medicine (Malabadi et al., 2021a; Tarasiuk et al., 2018).

Triphala is one of the oldest (1000 year) herbal medicine well documented in the Indian Ayurveda called the Charaka Samhita (Bhishagratna, 1963; Agnives'a et al., 1976; Baliga et al., 2012; Peterson et al., 2017). According to Charak Samhita (Indian Ayurveda), the daily oral consumption of Triphala Rasayana (Triphala with honey and ghee) has the potential to make a person live for one hundred years devoid of old age and diseases (Bhishagratna, 1963; Agnives'a et al., 1976; Baliga et al., 2012; Biradar et al., 2007; Peterson et al., 2017). Therefore, Triphala is called as the King of Ayurvedic herbal medicine which has been well documented in Sushruta Samhita text book in India formulated for many human health disorders (Bhishagratna, 1963; Agnives'a et al., 1976; Biradar et al., 2007 Biradar et al., 2007;Baliga et al., 2012; Verma et al., 2016; Peterson et al., 2017; Malabadi et al., 2021a). Therefore, Triphala is considered as a multipurpose therapeutic drug for many health disorders. Triphala is classified as a Tridoshic Rasayana, meaning as Energy and Immunity booster and appropriate for Vata, Pitta, and Kapha or all types of patients (Peterson et al., 2017; Baliga et al., 2012; Biradar et al., 2007; Shanbag, 2015; Pradeep et al., 2016; Peterson et al., 2017; Mamgain et al., 2016; Bhattacharjee R, et al., 2015; Shanbag, 2015; Pradeep et al., 2016; Peterson et al., 2017; Mamgain et al., 2016; Bhattacharjee R, et al., 2015). Triphala is also digestive, laxative at normal doses, bowel tonic at low dose, purgative at high doses, carminative, expectorant, antispasmodic, and bronchodilator (Baliga et al., 2012;
Biradar et al., 2007; Peterson et al., 2017; Belapurkar et al., 2014; Nariya et al., 2009; Rayudu and Raju, 2014).

According to Ayurvedic Rasayana, the taste of Triphala is defined as sweet, sour, pungent, bitter, and astringent but not salty with special mode of action or trophism for all doshas (energy, and immunity booster; mind and body types; for all ages, for all the disease) (Dhanalakshmi et al., 2007; Ozah, 2020; Mukherjee et al., 2006; Baliga et al., 2012; Peterson et al., 2017). Triphala extract exerted highly protective anti-aging effects on human skin cells in vitro. Therefore, potential dermal anti-aging effects of Triphala, such as increasing collagen and elastin, increasing cellular antioxidants, and decreasing hyper-pigmentation (Peterson et al., 2017; Verma et al., 2016; Baliga et al., 2012; Biradar et al., 2007; Shanbag, 2015; Pradeep et al., 2016; Peterson et al., 2017; Mamgain et al., 2016; Bhattacharjee R, et al., 2015). Triphala-derived polyphenols such as chebulinic acid are transformed by the human gut microbiota into metabolites such as urolithins which have the potential to prevent the oxidative damage (Baliga et al., 2012; Biradar et al., 2007;Peterson et al., 2017; Verma et al., 2016).

\section{Triphala: Pharmacology}

Triphala in Ayurvedic Rasayana formulation is used as a rejuvenative herbs, for the treatment of gastrointestinal tract disorders, prevents diarrhea, hypolipidemic effect, and reduces stress related problems, reducing the total cholesterol levels, and lowdensity lipoprotein (Tarasiuk et al., 2018; Srikumar et al., 2006; Saravanan et al., 2007; Maruthappan et al., 2010; Nariya et al., 2009, 2011; Peterson et al., 2017; Dhanalakshmi et al., 2007; Mukherjee et al., 2006; Baliga et al., 2012; Belapurkar et al., 2014; Kumari et al., 2009; Dhanalakshmi et al., 2007; Rasool and Sabina, 2007; Kumari et al., 2009). Triphala exerts hypoglycemic effects and showed antidiabetic activity by inhibiting the activity of pancreatic glycolytic enzymes, namely alpha-amylase and alpha-glucosidase, which break down larger polysaccharides into glucose molecules that enter the blood stream, thereby reducing blood glucose levels (Rajan and Antony, 2008; Yang et al., 2013; Ganeshpurkar et al., 2015; Peterson et al., 2017; Gurjar et al., 2012; Patel et al., 2012). Triphala also induces enteroprotective effects, due to the high antioxidant content. In additon to this, Triphala may also promote the proper digestion and absorption of food, reduce serum cholesterol levels, improve 
circulation, relax bile ducts, prevent immunosenescence, maintain homeostasis of the endocrine system, and increase the production of red blood cells and hemoglobin content (Baliga et al., 2012; Peterson et al., 2017; Belapurkar et al., 2014; Rasool and Sabina, 2007; Kumari et al., 2009; Mukherjee et al., 2006).

The other potential medicinal uses of Triphala, which include free radical scavenging, antioxidant, antifungal, antibacterial, antiviral, hypolipidemic effects, antimicrobial, antiallergic, anti-inflammatory, immunomodulating, appetite stimulation, gastric hyperacidity reduction, dental caries prevention, antipyretic, analgesic, antimutagenic, wound healing, anticariogenic, antistress, adaptogenic, hypoglycemic, anticancer, hepatoprotective, chemoprotective, radioprotective, and chemopreventive effects (Baliga et al., 2012; Zhang et al., 2021; Phetkate et al., 2012; Naik et al., 2005; Jagetia et al., 2002, 2004; Reddy et al., 2009; Gautam et al., 2012; Biradar et al., 2007, 2008;Peterson et al., 2017; Belapurkar et al., 2014; Nariya et al., 2009; Rayudu and Raju, 2014; Dhanalakshmi et al., 2007; Kalaiselvan and Rasool, 2016; Mukherjee et al., 2006; Rasool and Sabina, 2007; Kumari et al., 2009; Saxena et al., 2017). Triphala has been reported as a potential antineoplastic agent and Triphala exerts an antineoplastic effect on many cancer cell lines, including those of the breast, prostate, colon, and pancreas (Baliga, 2010, 2013; Kaur et al., 2005; Peterson et al., 2017; Vadde et al., 2015; Sandhya et al., 2006; Deshpande et al., 2014). Therefore, Triphala could be used as a potential adjunct therapy in the management of colon and other cancers.

Triphala is a rich source of vitamin $\mathrm{C}$, flavonoids and showed anti-cataract potential which helps in maintaining eye good health (Gupta et al., 2010; Peterson et al., 2017). Triphala also plays an important protective role in denistry and used as a mouth rinse (Prakash and Shelke, 2014; Srinagesh et al., 2012; Shanbag, 2015; Pradeep et al., 2016; Peterson et al., 2017; Mamgain et al., 2016; Bhattacharjee R, et al., 2015; Prabhakar et al., 2014; Tandon et al., 2010). The fruits of Terminalia chebula has anti-asthma, anti-tumor, stomach strengthening, expectorant, sore throat, and dyspnea effects and it is usually used to treat infectious diseases (Zhang et al., 2021). Terminalia bellirica fruits have the function of convergence, digestion, defecation, deworming, treatment of bronchitis, asthma, and ophthalmopathy (Zhang et al., 2021).

\section{Triphala: Biochemistry}

The major constituents of the Triphala formulations are the tannins, gallic acid, ellagic acid, and chebulinic acid, chebulagic acid which are potent antioxidants and therefore, resulted in the immunomodulatory activity without any side effects (Belapurkar et al., 2014; Baliga et al., 2012; Biradar et al., 2007; Peterson et al., 2017; Mukherjee et al., 2006; Rasool and Sabina, 2007; Kumari et al., 2009; Zhang et al., 2021). Gallic acid is a natural phenolic compound with various biological activities such as antioxidant, anti-inflammatory, antibacterial, anticancer, antiviral and cardiovascular protection (Zhang et al., 2021; Shanbag, 2015; Pradeep et al., 2016; Peterson et al., 2017; Mamgain et al., 2016; Bhattacharjee R, et al., 2015). Gallic acid not only destroys virus particles against A and B Influenza virus but also showed broad-spectrum antiviral activity. Therefore, gallic acid is a promising drug source for targeting viral particles. It exhibits concentrationdependent inhibition at higher concentrations. Moreover, gallic acid, methyl gallate and pentagalloyl glucose can inhibit the replication of IAV in MDCK cells, which may be a sensitive agent for inhibiting influenza A H1N1 influenza virus infection (Zhang et al., 2021). Triphala also contains other bioactive compounds such as flavonoids (e.g., quercetin and luteolin), saponins, anthraquinones, amino acids, fatty acids, and various carbohydrates. In addition, Triphaladerived polyphenols such as chebulinic acid are also transformed by the human gut microbiota into bioactive metabolites to prevent oxidative damage (Belapurkar et al., 2014; Baliga et al., 2012; Biradar et al., 2007; Peterson et al., 2017; Mukherjee et al., 2005; Rasool and Sabina, 2007; Kumari et al., 2009). Further, 1,2,3,4,6-penta-O-galloyl- $\beta$-D-glucopyranose (PGG) is a more common tannin compound in Triphala which exhibit antiviral effects. Excoecariphenol D, corilagin, geraniin and chebulagic acid also showed potential inhibitory effects on HCV NS3-4A protease (Zhang et al., 2021). The 1,2,3,4,6-penta-O-galloyl- $\beta$-D-glucopyranose (PGG) antiviral mechanisms include direct inactivation, inhibition of virus adsorption on host cells and expression of viral genes, and protein translation inhibition of replicated viral genomes (Zhang et al., 2021). Triphala contains a variety of acyl-glucose and has a variety of antiviral effects, such as HIV, and antiviral drugs for severe acute respiratory syndrome coronavirus (SARS-CoV) (Zhang et al., 2021). The 1,2,6-Trigalloyl-â-D-glucose and 1,2,3,6-tetra-Ogalloyl- â-D-glucose have a significant inhibitory effect 
on HCV NS3 protease (Zhang et al., 2021). The fruit of Emblica officinalis has the functions of diuresis, invigorating stomach, and can be used for diarrhea. In addition, Emblica officinalis has many pharmacological activities, namely, anti-diabetic, antioxidant, antimicrobial, anti-fungal, anti-allergic, anti-viral and anticancer properties (Zhang et al., 2021).

\section{Triphala: Coronavirus}

Clinical settings and regulations of research on Covid19 through Ayurveda, Unani, Siddha, and Homeopathy systems have already been published by the Indian Ministry of Ayush, Government of India, New Delhi, India (INDIA, 2020; Silveira et al., 2020; Malabadi et al., 2021; Rastogi et al., 2020; Ozah, 2020). Triphala with main components and common phenolic tannin compounds have different degrees of antiviral effects, which can inhibit DNA viruses, such as Herpes simplex virus type-1 (HBV) and simplex virus type (HSV). Furthermore, Triphala have inhibitory effects on many RNA viruses, such as human immunodeficiency virus type 1 (HIV-1), RSV, hepatitis C virus (HCV), rabies virus (RABV), human rhinovirus (HRV), influenza A virus (IAV) and human coronavirus (Zhang et al., 2021). Moreover, Triphala has obvious antioxidative stress and antiviral immunity, and promoted hypoxia tolerance and lung injury repair (Zhang et al., 2021). In an in vitro experiments, gallic acid, caffeic acid and chlorogenic acid of Triphala herbal formulation can reduce the production of progeny of human coronavirus, HCoV-NL63 particles and have an antiviral effect (Zhang et al., 2021).

Terminalia bellirica is effective against all three HIV-1 pseudoviruses with the least cytotoxicity and the greatest antiviral potential (Zhang et al., 2021). The compounds extracted from Terminalia bellirica can be used as HIV reverse transcriptase and have anti-HIV-1, antimalarial and antifungal activities (Zhang et al., 2021).

Ellagic acid has antiviral activity against human rhinovirus (HRV) and Ebola virus (EV) (Zhang et al., 2021). Ellagic acid has different inhibitory effects on a variety of viruses (Zhang et al., 2021). Further, both chebulagic acid and chebulinic acid also showed an in vitro antiviral activity (Zhang et al., 2021). In one of the study, chebulagic acid treatment of lethal human enterovirus 71 (EV71)-attacking mice can effectively reduced the mortality and relieved the symptoms by inhibiting virus replication. Therefore, chebulagic acid may be a potential therapeutic agent for EV71 infection (Zhang et al., 2021).

Corilagin inhibits Herpes simplex virus type-1 (HBV), reduces the cytotoxicity of EV71 or Coxsackie virus A16 to Vero cells has a protective effect against Japanese encephalitis virus (JEV)-induced Parkinson's disease, and HIV viral infection showed high antiviral activity (Zhang et al., 2021). In addition, gallic acid is also resistant to dengue virus (DENV), HBV, EV71 and EV (Zhang et al., 2021).

The compounds extracted from Emblica officinalis also have antiviral functions (Baliga, 2010; Baliga et al., 2012, 2013; Zhang et al., 2021; Malabadi et al., 2021). One of the study found that 1,2,4,6-tetra-O-galloyl-â-Dglucose (1246-TGG) extracted from Emblica officinalis can significantly resist the infection with herpes simplex virus type-1 (HSV-1) and herpes simplex virus type-2 (HSV-2) at nontoxic concentrations (Zhang et al., 2021). The sesquiterpene glycosides extracted from Emblica lanceolata and the main tannin compound Phyllaemblicin B, Euglyceroside B has a strong activity against Cox sackie virus B3 (CVB3) (Zhang et al., 2021). Pharmacological studies have shown that Terminalia chebula has an inhibitory effect on viral infections such as human immunodeficiency virus type 1 (HIV-1), herpes simplex virus type 1 (HSV-1) cytomegalovirus (CMV) and influenza A virus (IAV) (Zhang et al., 2021). Terminalia chebula are rich in hydrolyzable tannins with good antiviral activity (Zhang et al., 2021).

In India, Triphala is commercially available in local market under different brand names, 1) Himalaya Herbal drugs- Triphala powder and in the form of tablets, 2) Dabur-Triphala Churna powder, 3) ZanduTriphala Churna powder, 4) Pure Indian Foods-Triphala in Ghee, 5) Baidynath-Triphala juice; Triphala Churna powder, 6) JIVA Organic Triphala powder, 7) Organic India- Triphala Herbal Supplement- Triphala powder, 8) SEWANTH'S-Triphala supplemented with Phyllanthus niruri and Glycyrrhiza glabra, 9) KAPIVA AyurvedaTriphala natural herbal juice, 10) Gopala Ayurveda.com-Triphala capsules.

In India, during the recent outbreak of coronavirus, SARS-CoV-2 with mutated strains, Delta (B.1.617.2) and Delta Plus (AY.1), the products of Triphala have reached very high demand and there was a shortage of 
supply, selling at high price, and people were struggling to get Triphala. Therefore, most of local people in the rural areas of Karnataka state, India including traditional herbal healers were helping Covid-19 patients with Triphala, an alternative herbal medicine as a immunity booster. In addition to this, the local traditional healers in Karnataka, Tamil Nadu, Kerala, Goa, Andhra Pradesh, Telangana, Maharashtra states, India have also helped Covid-19 patients with Triphala and additional supplementation. Triphala is consumed with coconut water as an additional supplementation. Triphala powder is also mixed with sugar cane juice which is rich in mineral nutrients, sweet in taste for the oral consumption for children's and elderly people. Some of the traditional healers were also practicing the consumption of Triphala with diluted Azadirachta indica (Neem) juice with strong antiviral properties. In addition to this, Triphala with Aloe vera (Aloe barbadensis ) juice is also used as an additional supplementation. Triphala is also consumed with fruit juice containing melatonin rich drink (Malabadi et al., 2021c).

Among all these additional supplementations, one of the interesting herbal formulation is Triphala is consumed with pumpkin seeds. The rationale behind the use of pumpkin (Cucurbita pepo) or Cucurbita moschata seeds belongs to the family Cucurbitaceae (Fu et al., 2006; Meru et al., 2017) is an important nutritious diet rich in antioxidants and zinc. Pumpkin seed contains significant levels of antioxidants (tocopherols and tocotrienols) and zinc. The high levels of unsaturated fatty acids (oleic and linoleic acids) in pumpkin seed oil provide health benefits that reduces the risks of arteriosclerosis and heart-related ailments (Stevenson et al., 2007; Fu et al., 2006; Meru et al., 2017). The pumpkin seeds are rich in zinc, protein, fibers, minerals like iron, zinc, calcium, magnesium, manganese, copper, sodium, and PUFA (polyunsaturated fatty acids), phytosterol, vitamins and antioxidants (Muscogiuri et al., 2020). Antioxidant and zinc rich in pumpkin seeds inhibit the coronavirus (SARS) activity (Velthuis et al., 2010; Muscogiuri et al., 2020). Antioxidants increase the number of T-cell subsets, enhance lymphocyte response, increased interleukin-2 production, potentiated natural killer cell activity, and increased response to influenza virus vaccine compared with placebo (Muscogiuri et al., 2020).

In general, Covid-19 patients admitted in hospital are suffering from malnutrition. Therefore, dietary therapy with Triphala plays an important role as a immunity booster. Covid-19 patient diet should contain source of vitamin E, vitamin D, antioxidants, Beta Carotene and zinc (Muscogiuri et al., 2020). The major dietary sources of vitamin $\mathrm{E}$ are vegetable oils (soybean, sunflower, corn, wheat germ, and walnut), nuts, seeds, spinach, and broccoli (Muscogiuri et al., 2020). Vitamin D deficiency has been associated to viral epidemics and significantly higher risk of death from respiratory tract infections (Chandra, 1992; Muscogiuri et al., 2020). Further, vitamin D protects respiratory tract preserving tight junctions, killing enveloped viruses through induction of cathelicidin and defences, and decreasing production of pro-inflammatory cytokines by the innate immune system, therefore reducing the risk of a cytokine storm leading to pneumonia (Muscogiuri et al., 2020). Therefore Covid19 patients are encouraged to get more vitamin D from diet (Muscogiuri et al., 2020). Foods containing vitamin D include fish, liver, egg yolk and foods (e.g., milk, yogurt) with added vitamin D (Muscogiuri et al., 2020). Beta Carotene is the most abundant in sweet potatoes, carrots, and green leafy vegetables while sources of vitamins $\mathrm{C}$ include red peppers, oranges, strawberries, broccoli, mangoes, lemons, and other fruits and vegetables (Muscogiuri et al., 2020).

Another essential trace element that is crucial for the maintenance of immune function is zinc. It has been reported that zinc inhibited severe acute respiratory syndrome (SARS) coronavirus RNA-dependent RNA polymerase (RdRp) template binding and elongation in Vero-E6 cells (Velthuis et al., 2010; Muscogiuri et al., 2020). Although oysters contain the most of the zinc per serving, the most common food to get zinc are represented from poultry, red meat, nuts, pumpkin seeds, sesame seeds, beans, lentils, olive oil, fresh fruits and vegetables, protein-rich legumes, and fish (Muscogiuri et al., 2020).

\section{Conclusions}

This review paper has presented some of the interesting and important medicinal properties of Triphala, which is one of the age old Indian folk medicine. Triphala has been used for combating many human health disorders including viral diseases. On the basis of literature survey, there are few reports of Triphala inhibiting coronavirus activity. During the recent outbreak of coronavirus mutants, Delta (B.1.617.2) and Delta Plus (AY.1), Triphala with additional supplementation of 
pumpkin seeds, sugar cane juice, Aloe vera juice, neem juice, and melatonin was more effective in boosting the immunity in Covid-19 patients than Triphala alone. However, there are no proven Covid-19 clinical trials for the scientific validiation of Triphala. Therefore, clinical trials particularly with Covid-19 could be the new ray of hope in dealing with viral infections. One of the author Silveira et al., (2020) recently coated that herbal medicines are not a magic bullet" to solve the problems related to flu - let alone Covid-19 or any other coronavirus (Silveira et al., 2020). Herbal folk medicines neither can avoid the virus infection but may alleviate symptoms and potentially improve the general wellbeing of patients. It requires a careful assessment of whether such Triphala adjuvant therapies are justified or not. Triphala can only be a suitable therapy at a stage when the severity of the disease is minor For an herbal medicine to be a medicine of high quality, chemically well-characterized, and pharmacologically well-studied preparations are acceptable only. For successful and effective development of a drug, the basic requirement is the correct identification of the source of biologically active compound, its availability and processing. Therefore, a rigorous and evidence-based Triphala with additional supplementations approach will have a balanced assessment of such medicines.

\section{Conflict of interest statement}

Authors declare that they have no conflict of interest.

\section{References}

Agnives'a, Cakrapanidatta, Sarma, RM, Dash B (1976) Agniveas's Caraka samhita: Text with English Translation \& Critical Exposition Based on Cakrap_ani Datta's Ayurveda dipik_a, 1st ed. Varanasi, India: Chowkhamba Sanskrit Series Office, 1976.

Baliga MS (2010) Triphala, Ayurvedic formulation for treating and preventing cancer: A review. J Altern Complement Med. 16: 1301-1308.

Baliga MS et al., (2012) Scientific validation of the ethnomedicinal properties of the Ayurvedic drug Triphala: A review. Chin J. Integr. Med.18:946954.

Baliga MS, Meera S, Vaishnav LK, et al., (2013) Rasayana drugs from the Ayurvedic system of medicine as possible radioprotective agents in cancer treatment. Integr Cancer Ther. 12:455-463.

Baskaran UL, Martin SJ, Mahaboobkhan R, Prince SE
(2015) Protective role of Triphala, an Indian traditional herbal formulation, against the nephrotoxic effects of bromobenzene in Wistar albino rats. J.Integr Med. 13:115-121.

Belapurkar P, Goyal P, Tiwari-Barua P (2014) Immunomodulatory effects of Triphala and its individual constituents: A review. Indian J Pharm Sci. 76:467-475.

Bhattacharjee R, et al., (2015) Efficacy of Triphala mouth rinse (aqueous extracts) on dental plaque and gingivitis in children. J. Investig Clin Dent. 6:206210.

Bhishagratna K (1963) An English Translation of the Sushruta Samhita, Based on Original Sanskrit Text, with a Full and Comprehensive Introduction., Additional Texts, Different Readings, Notes, Comparative Views, Index, Glossary And Plates, 2nd ed. Varanasi, India: Chowkhamba Sanskrit Series Office, 1963.

Biradar YS et al., (2007) Evaluation of anti-diarrhoeal property and acute toxicity of Triphala Mashi, an Ayurvedic formulation. J. Herb Pharmacother. 7:203-212.

Biradar YS, Jagatap S, Khandelwal KR, Singhania SS (2008) Exploring of antimicrobial activity of Triphala Mashi-An ayurvedic formulation. Evid Based Complement Altern Med. 5:107-113.

Chandra RK (1992) Effect of vitamin and trace-element supplementation on immune responses and infection in elderly subjects. Lancet. 340:1124-7.

Deshpande A, Tandon S, Deshpande N (2014) Low resource screening method of pre-cancerous lesions and its reversal by Triphala in teen-age Indian population. Ayu. 35: 160-167.

Dhanalakshmi S, Devi RS, Srikumar R, et al., (2007) Protective effect of Triphala on cold stress-induced behavioral and biochemical abnormalities in rats. Yakugaku Zasshi. 127:1863-1867.

Fu, C, Shi H, Li Q (2006) A review on pharmacological activities and utilization technologies of pumpkin. Plant Foods Hum. Nutr. 61(2):73-80.

Ganeshpurkar A, Jain S, Agarwal S (2015) Experimental studies on glycolytic enzyme inhibitory and antiglycation potential of Triphala. Ayu. 36:96-100.

Gautam AK, Avasthi S, Sharma A, Bhadauria R (2012) Antifungal potential of Triphala churna ingredients against Aspergillus species associated with them during storage. Pak J Biol Sci. 15:244-249.

Gupta SK, Kalaiselvan V, Srivastava S, et al., (2010) Evaluation of anticataract potential of Triphala in 
selenite-induced cataract: In vitro and in vivo studies. J. Ayurveda Integr Med . 1:280-286.

Gurjar S, Pal A, Kapur S (2012) Triphala and its constituents ameliorate visceral adiposity from a high-fat diet in mice with diet-induced obesity. Altern Ther Health Med. 18:38-45.

INDIA (2020). "Notification for undertaking research on Covid-19 through Ayurveda, Unani, Siddha and Homoeopathy systems," in L.11011/8/2020/AS (New Delhi: Ministry of Ayush).

Jagetia GC, Baliga MS, Malagi KJ, Sethukumar Kamath M (2002) The evaluation of the radioprotective effect of Triphala (an ayurvedic rejuvenating drug) in the mice exposed to gammaradiation. Phytomedicine. 9:99-108.

Jagetia GC, Malagi KJ, Baliga MS, et al., (2004) Triphala, an ayurvedic rasayana drug, protects mice against radiation induced lethality by free-radical scavenging. J. Altern Complement Med. 10:971978.

Kalaiselvan S, Rasool MK (2016) Triphala herbal extract suppresses inflammatory responses in LPSstimulated RAW 264.7 macrophages and adjuvantinduced arthritic rats via inhibition of NF-kappaB pathway. J Immunotoxicol. 13:509-525.

Kambhar SV, Patil RR, Dandinnavar S, Hirekudi S (2020) Ethnobotanical Survey of Medicinal plants in Raibag, Belagavi, Karnataka. International Journal of Botany Studies. 5(6): 83-86.

Kaur S, Michael H, Arora S, et al., (2005) The in vitro cytotoxic and apoptotic activity of Triphala-An Indian herbal drug. J. Ethnopharmacol. 97:15-20.

Kawalekar J (2011) Survey and documentation of some of antidiabetic used by local vaidyas in Gavanal village, at Hukkeri taluka, Belgaum District. Plant Sciences Feed. 1 (3): 34-38.

Kawalekar JS (2012) Medicinal plants used by local vaidyas in Gavanal village, At Hukkeri Taluk, Belgaum district. INTERNATIONAL JOURNAL OF PHYTOTHEARPY RESEARCH. 1(2): 1-7.

Kulkarni SA, Nagarajan SK, Ramesh V, Palaniyandi V, Selvam SP, Madhavan T (2020) Computational evaluation of major components from plant essential oils as potent inhibitors of SARS CoV- 2 spike protein. J. Molec Struct. 1221:128823. (https ://doi. org/10.1016/j.molst ruc.2020.12882 3).

Kumari N, et al., (2009) Effects of ionizing radiation on microbial decontamination, phenolic contents, and antioxidant properties of triphala. J Food Sci. 74: M109-M113.

Laddimath A, Rao S (2016) Herbal medicine used to treat primary infertility in women by traditional practioners of Vijayapur (Bijapur) district of Karnataka, India. International Letters of Natural Sciences. $50: 27-32$. ISSN: 2300-9675.

Malabadi RB (2005) Antibacterial activity in the rhizome extract of Costus speciosus (Koen.). Journal of Phytological Research. 18 (1): 83-85.

Malabadi RB (2008) Production of edible vaccines for oral immunization in transgenic plants, current and future prospective. Journal of Phytological Research. 21(1): 1-10.

Malabadi RB, Nataraja K (2002a) Peroxidase activity as a marker of xylogenesis in the cultured cells of Guava (Psidium guajava L.). Indian Journal of Forestry. 25(2): 196-200.

Malabadi RB, Nataraja K (2002b) In vitro plant regeneration in Clitoria ternatea. Journal of Medicinal and Aromatic Plant Sciences. 24: 733737.

Malabadi RB, Chalannavar RK (2020) Safed musli (Chlorophytum borivilianum): Ethnobotany, phytochemistry and pharmacological updates. Int. J. Curr. Res. Biosci. Plant Biol. 7(11): 25-31.

Malabadi RB, Chalannavar RK, Supriya S, Nityasree BR, Sowmyashree K, Meti NT (2018) Role of botanical drugs in controlling dengue virus disease. International Journal of Research and Scientific Innovations. 5(7): 134-159.

Malabadi RB, Chalannavar RK, Meti NT, Gani RS, Vijayakumar S, Mulgund GS, Masti S, Chougale R, Odhav B, Sowmyashree K, Supriya S, Nityasree BR, Divakar MS (2016c) Insulin plant, Costus speciosus: Ethnobotany and pharmacological updates. Int.J. Curr. Res. Biosci. Plant Biol. 3(7): 151-161.

Malabadi RB, Chalannavar RK, Meti NT, Mulgund GS, Nataraja K, Vijayakumar S (2012a) Synthesis of antimicrobial silver nanoparticles by callus cultures and in vitro derived plants of Catharanthus roseus. Research in Pharmacy. 2(6):18-31.

Malabadi RB, Chalannavar RK, Meti NT, Vijayakumar S, Mulgund GS, Gani RS, Supriya S, Sowmyashree K, Nityasree BR, Chougale A, Divakar MS (2016d) Antidiabetic Plant, Gymnema sylvestre R. Br., (Madhunashini): Ethnobotany, phytochemistry and pharmacological updates. International Journal of Current Trends in Pharmacobiology and Medical Sciences. 1(4): 1-17.

Malabadi RB, Chalannavar RK, Sowmyashree K, Supriya S, Nityasree BR, Gleiser RM, Meti NT, Vijayakumar S, Mulgund GS, Gani RS, Nasalapure 
A, Chougale R, Masti S, Chougale A, Divakar MS, Kasai D, Odhav B, Baijnath H (2016a) Ebola virus: Updates on plant made vaccine development. International Journal of Research and Scientific Innovations. 3(6):4-12.

Malabadi RB, Chalannavar RK, Supriya S, Nityasree BR, Sowmyashree K, Mulgund GS, Meti NT (2017a) Dengue virus disease: Recent updates on vaccine development. International Journal of Research and Scientific Innovations. 4(7):08-29.

Malabadi RB, Chalannavar RK, Supriya S, Nityasree BR, Sowmyashree K, Mulgund GS, Meti NT (2017b) Dengue virus disease: Current updates on the use of Carica papaya leaf extract as a potential herbal medicine. International Journal of Research and Scientific Innovations. 4(8):36-50.

Malabadi RB, Ganguly A, Teixeira da Silva JA, Parashar A, Suresh MR, Sunwoo HH (2011a) Overview of plant-derived vaccine antigens: dengue virus. J. Pharm. Pharm. Sci. 14: 400- 413.

Malabadi RB, Kolkar KP, Meti NT, Chalannavar RK (2021c) Melatonin: One molecule one- medicine for many diseases, coronavirus (SARS-CoV-2) disease (Covid-19); Function in plants. International Journal of Research and Scientific Innovations. 8(3): 155181.

Malabadi RB, Kolkar KP, Meti NT, Chalannavar RK (2021d) Vaccine development for coronavirus (SARS-CoV-2) disease (Covid-19): Lipid nanoparticles. International Journal of Research and Scientific Innovations. 8(3): 189-195.

Malabadi RB, Kolkar KP, Meti NT, Chalannavar RK (2021e) Role of botanical essential oils as a therapy for controlling coronavirus (SARS-CoV-2) disease (Covid-19). International Journal of Research and Scientific Innovations. 8(4): 105-118.

Malabadi RB, Kolkar KP, Meti NT, Chalannavar RK (2021f) Role of plant based hand sanitizers during the recent outbreak of coronavirus (SARS-CoV-2) disease (Covid-19). Significances of Bioengineering \& Biosciences. 5(1): 458-468.

Malabadi RB, Kolkar KP, Meti NT, Chalannavar RK (2021g) Outbreak of Coronavirus (SARS-CoV-2) Delta variant (B.1.617.2) and Delta Plus (AY.1) with fungal infections, Mucormycosis: Herbal medicine treatment. International Journal of Research and Scientific Innovations. 8(6): 59-70.

Malabadi RB, Kolkar KP, Meti NT, Chalannavar RK (2021h) Camphor tree, Cinnamomum camphora (L.); Ethnobotany, and pharmacological updates. Biomedicine. 41 (2): 181-184.
Malabadi RB, Kolkar KP, Meti NT, Chalannavar RK (2021j) Recent updates on role of herbal medicine for Alzheimer's disease (Dementia). Int. J. Curr. Res. Biosci. Plant Biol. 8(1): 14-32.

Malabadi RB, Lokare-Naik S, Meti NT, Mulgund GS, Nataraja K, Vijayakumar S (2012d) Synthesis of silver nanoparticles from in vitro derived plants and callus cultures of Clitoria ternatea; Evaluation of antimicrobial activity. Research in Biotechnology. 3(5): 26- 38.

Malabadi RB, Meti NT, Chalannavar RK (2021a) Role of herbal medicine for controlling coronavirus (SARS-CoV-2) disease (Covid-19). International Journal of Research and Scientific Innovations. 8(2): 135-165.

Malabadi RB, Meti NT, Chalannavar RK (2021b) Applications of nanotechnology in vaccine development for coronavirus (SARS-CoV-2) disease (Covid-19). International Journal of Research and Scientific Innovations. 8(2): 191-198.

Malabadi RB, Meti NT, Chalannavar RK (2021i) Updates on herbal remedy for kidney stone chronic disease. International Journal of Research and Scientific Innovations. 8(2):122-134.

Malabadi RB, Meti NT, Mulgund GS, Nataraja K, Vijayakumar S (2012b) Synthesis of silver nanoparticles from in vitro derived plants and callus cultures of Costus speciosus (Koen.); Assessment of antibacterial activity. Research in Plant Biology. 2(4):32-42.

Malabadi RB, Mulgund GS, Meti NT, Nataraja K, Vijayakumar S (2012c) Antibacterial activity of silver nanoparticles synthesized by using whole plant extracts of Clitoria ternatea. Research in Pharmacy. 2(4):10-21.

Malabadi RB, Mulgund GS, Nataraja K (2005) Screening of antibacterial activity in the extracts of Clitoria ternatea (Linn.). Journal of Medicinal and Aromatic Plant Sciences. 27: 26- 29.

Malabadi RB, Mulgund GS, Nataraja K (2007) Ethanobotanical survey of medicinal plants of Belgaum district, Karnataka, India. Journal of Medicinal and Aromatic Plant Sciences. 29 (2):7077.

Malabadi RB, Mulgund GS, Nataraja K (2009) Triacontanol induced somatic embryogenesis and plantlet regeneration in Catharanthus roseus. Journal of Medicinal and Aromatic Plant Sciences. 31: 147-151.

Malabadi RB, Mulgund GS, Nataraja K (2010a) Evaluation of antifungal activity of selected 
medicinal plants. Journal of Medicinal and Aromatic Plant Sciences. 32(1):42-45.

Malabadi RB, Parashar A, Ganguly A, Suresh MR (2010b) Expression of dengue virus envelope protein in a different plant system. Faculty Research and Development day, Faculty of Pharmacy and Pharmaceutical Sciences, University of Alberta, Edmonton, Canada, 19th November 2010. Abstract No-69, page.

Malabadi RB, Vijayakumar S, Mulgund GS, Nataraja K (2011b) Induction of somatic embryogenesis in papaya (Carica papaya). Research in Biotechnology. 2(5):40-55.

Malabadi RB, Vijaykumar S (2005) Assessment of antidermatophytic activity of some medicinal plants. Journal of Phytological Research. 18 (1):103-106.

Malabadi RB, Vijaykumar S (2007) Assessment of antifungal activity of some medicinal plants. International Journal of Pharmacology. 3 (6):499504.

Malabadi RB, Vijaykumar S (2008) Evaluation of antifungal property of medicinal plants. Journal of Phytological Research. 21(1):139-142.

Mamgain P, Kandwal A, Mamgain RK (2016) Comparative evaluation of triphala and ela decoction with $0.2 \%$ chlorhexidine as mouthwash in the treatment of plaque-induced gingivitis and halitosis:Arandomized controlled clinical trial. J. Evid Based Complement Altern Med. DOI:10.1177/ 2156587216679532.

Maruthappan V, Shree KS (2010) Hypolipidemic activity of haritaki (Terminalia chebula) in atherogenic diet induced hyperlipidemic rats. J. Adv Pharm Technol Res. 1: 229-235.

Meru G, Fu Y, Leyva D, Sarnoski P, Yagiz Y (2017) Health Benefits of Pumpkin Seed and Nutrition Profile of 35 Pumpkin Accessions. This document is HS1312, one of a series of the Horticultural Sciences Department, UF/IFAS Extension. Original publication date November 2017. Visit the EDIS website at http://edis.ifas.ufl.edu.

Ministry of Ayush (2020) National Clinical Management Protocol based on Ayurveda and Yoga for management of Covid-19. Ministry of Ayush, Government of India, New Delhi, India.

Mlcochova P, Kemp S, Dhar MS, Papa G, Meng B, Mishra S, Whittaker C, Mellan T, Ferreira I, Datir R, Collier DA, Singh S, Pandey R, Marwal R, Datta M, Sengupta S, Ponnusamy K et al., (2021) SARS-CoV-2 B.1.617.2 Delta variant emergence and vaccine breakthrough. Research Square. https://doi.org/10.21203/rs.3.rs-637724/v1

Mukherjee PK, Bhattacharyya SRS, Debnath PK, Biswas TK et al., (2006) Clinical study of 'Triphala'-A well known phytomedicine from India. Iran J Pharmacol Ther. 5(1):51-54.

Muscogiuri G, Barrea L, Savastano S, Colao A (2020) Nutritional recommendations for Covid-19 quarantine. European Journal of Clinical Nutrition. 74:850-851. (https://doi.org/10.1038/s41430-0200635-2).

Naik GH, et al., (2005) In vitro antioxidant studies and free radical reactions of triphala, an ayurvedic formulation and its constituents. Phytother Res. 19:582-586.

Nariya M, Shukla V, Jain S, Ravishankar B (2009) Comparison of enteroprotective efficacy of Triphala formulations (Indian herbal drug) on methotrexateinduced small intestinal damage in rats. Phytother Res. 23:1092-1098.

Nariya MB, Shukla VJ, Ravishankar B, Jain SM (2011) Comparison of gastroprotective effects of triphala formulations on stress-induced ulcer in rats. Indian J Pharm Sci. 73: 682-687.

Ozah B (2020) Triphala: A useful therapeutic supplement during COVID-19 pandemic. Journal of Drug Delivery and Therapeutics. 10(4):219-220 . (http://dx.doi.org/10.22270/jddt.v10i4.4153).

Patel DK, Kumar R, Laloo D, Hemalatha S (2012) Diabetes mellitus: An overview on its pharmacological aspects and reported medicinal plants having antidiabetic activity. Asian Pac J Trop Biomed. 2:411-420.

Peterson CT, Denniston K, Chopra D (2017) Therapeutic uses of Triphala in Ayurvedic medicine.

Phetkate P, Kummalue TYUP, Kietinun S (2012) Significant increase in cytotoxic $\mathrm{T}$ lymphocytes and natural killer cells by triphala: A clinical phase I study. Evid Based Complement Altern Med. 2012:239856.

Prabhakar J, Balagopal S, Priya MS, et al., (2014) Evaluation of antimicrobial efficacy of Triphala (an Indian Ayurvedic herbal formulation) and $0.2 \%$ chlorhexidine against Streptococcus mutans biofilm formed on tooth substrate: An in vitro study. Indian J. Dent Res. 25:475-479.

Pradeep AR, et al., (2016) Triphala, a new herbal mouthwash for the treatment of gingivitis: A randomized controlled clinical trial. J. Periodontol. 87:1352-1359.

Prakash S, Shelke AU (2014) Role of Triphala in 
dentistry. J. Indian Soc Periodontol. 18:132-135.

Rajan SS, Antony S (2008) Hypoglycemic effect of triphala on selected non insulin dependent diabetes mellitus subjects. Ancient Sci Life. 27:45-49.

Rasool M, Sabina EP (2007) Anti-inflammatory effect of the Indian Ayurvedic herbal formulation Triphala on adjuvant induced arthritis in mice. Phytother Res. 21:889-894.

Rastogi S, Pandey DN, Singh RH (2020) COVID-19 Pandemic: A pragmatic plan for Ayurveda Intervention. J. Ayurveda Integr. Med. Res. doi: 10.1016/j.jaim.2020.1004.1002.

Rayudu V, Raju AB (2014) Effect of Triphala on dextran sulphate sodium-induced colitis in rats. Ayu. 35:333-338.

Reddy DB, et al., (2009) Chebulagic acid, a COX-LOX dual inhibitor isolated from the fruits of Terminalia chebula Retz., induces apoptosis in COLO-205 cell line. J. Ethnopharmacol. 124:506-512.

Sandhya T, Lathika KM, Pandey BN, Mishra KP (2006) Potential of traditional ayurvedic formulation, Triphala, as a novel anticancer drug. Cancer Lett. 231:206-214.

Saravanan S, Srikumar R, Manikandan S, et al., (2007) Hypolipidemic effect of triphala in experimentally induced hypercholesteremic rats. Yakugaku Zasshi. 127:385-388.

Saxena S, Lakshminarayan N, Gudli S, Kumar M (2017) Anti bacterial efficacy of Terminalia chebula, Terminalia bellirica, Embilica officinalis and Triphala on salivary streptococcus mutans count-A linear randomized cross over trial. J. Clin Diagn Res. 11:ZC47-ZC51.

Shanbhag VK (2015) Triphala in prevention of dental caries and as an antimicrobial in oral cavity-A review. Infect Disord Drug Targets. 15:89-97.

Sharma T (2009) Ethnobotany and Medicinal plants of India and Nepal. Vol-3, 1-338. Scientific Publishers (India), 5-A, New Pali Road, P.O. Box 91, Jodhpur - 342001 (India); ISBN: 978-81-7233603-5 (Vol. 3); 978-81-7233-605-9 (Set)

Silveira D, Prieto-Garcia JM, Boylan F, Estrada O, Fonseca-Bazzo YM, Jamal CM, Magalhães PO, Pereira EO, Tomczyk M and Heinrich M (2020) Covid-19: Is There Evidence for the Use of Herbal Medicines as Adjuvant Symptomatic Therapy?. Front. Pharmacol. 11: 581840.

Srikumar R, Parthasarathy NJ, Manikandan S, et al., (2006) Effect of Triphala on oxidative stress and on cell-mediated immune response against noise stress in rats. Mol Cell Biochem. 283:67-74.
Srinagesh J, Krishnappa P, Somanna SN (2012) Antibacterial efficacy of Triphala against oral streptococci: An in vivo study. Indian J Dent Res. 23:696.

Stevenson DG, Eller FJ, Wang L, Jane JL, Wang T, Inglett GE (2007) Oil and tocopherol content and composition of pumpkin seed oil in 12 cultivars. J. Agric. Food Chem. 55:4005-4013.

Tandon S, Gupta K, Rao S, Malagi KJ (2010) Effect of Triphala mouthwash on the caries status. Int $\mathbf{J}$ Ayurveda Res. 1: 93-99.

Tarasiuk A, Mosińska P, Fichna J (2018) Triphala: Current applications and new perspectives on the treatment of functional gastrointestinal disorders. Chinese Medicine. 13:39. (https://doi.org/10.1186/s13020-018-0197-6).

The Journal of Alternative and Complementary Medicine. 23(8): 607-614. Mary Ann Liebert, Inc. (DOI: 10.1089/acm.2017.0083).

Upadhya V, Hegde HV, Bhat S, Kholkute SD (2014) Non-codified traditional medicine practices from Belgaum Region in Southern India: present scenario. Journal of Ethnobiology and Ethnomedicine. 10:49

Vadde R, Radhakrishnan S, Reddivari L, Vanamala JK. Triphala extract suppresses proliferation and induces apoptosis in human colon cancer stem cells via suppressing c- Myc/cyclin D1 and elevation of Bax/Bcl-2 ratio. Bio-Med Res Int. 2015:649263.

Varma SR, et al., (2016) Protective effects of triphala on dermal fibroblasts and human keratinocytes. PLoS One. 11: $\mathrm{e} 0145921$.

Velthuis AJ, van den Worm SH, Sims AC, Baric RS, Snijder EJ, van Hemert MJ (2010) Zn(2+) inhibits coronavirus and arterivirus RNA polymerase activity in vitro and zinc ionophores block the replication of these viruses in cell culture. PLoS Pathog. 2010;6: e1001176.

Wu F, Zhao S, Yu B, Chen YM, Wang W, Song ZG, $\mathrm{Hu} \mathrm{Y}$, Tao ZW, Tian JH, Pei YY, Yuan ML, Zhang YL, Dai FH, Liu Y, Wang QM, Zheng JJ, Xu L, Holmes EC, Zhang YZ (2020a) A new coronavirus associated with human respiratory disease in China. Nature. 579 (7798) 265-269.

Wu YQ, Zou L, Yu X, Sun D, Li SB, Tang L, Yang JR, Chen XY, Wu YG, Fang H (2020b) Clinical effects of integrated traditional Chinese and western medicine on Covid-19: A systematic review. Shanghai J. Tradit. Chin. Med. 1-8.

Yang (2021) Application of nanotechnology in the Covid-19 pandemic. International Journal of 
Nanomedicine. $6: 623-649$.

Yang MH, Vasquez Y, Ali Z, et al., (2013) Constituents from Terminalia species increase PPARalpha and PPARgamma levels and stimulate glucose uptake without enhancing adipocyte differentiation. J. Ethnopharmacol. 149:490-498.

Zhang Y, Fan Q, Fan Y, Tao Liu T (2021) A Review of antiviral research on Tibetan medicine Triphala. EC Neurology. SI.02: 195-205.
Zhou P, Yang XL, Wang XG, Hu B, Zhang L, Zhang W et al., (2020b) A pneumonia outbreak associated with a new coronavirus of probable bat origin. Nature. 579: 270-273.

Zhou P, Yang XL, Wang XG, Hu B, Zhang L, Zhang W et al., (2020a) Discovery of a novel coronavirus associated with the recent pneumonia outbreak in humans and its potential bat origin. Nature. 579: $270-273$.

\section{How to cite this article:}

Malabadi, R. B., Kolkar, K. P., Meti, N. T., Chalannavar, R. K., 2021. Triphala: An Indian Ayurvedic herbal formulation for coronavirus (SARS-CoV-2) disease (Covid-19). Int. J. Curr. Res. Biosci. Plant Biol., 8(8): 18-30.

doi: https://doi.org/10.20546/ijcrbp.2021.808.003 